\title{
A new Caulokaempferia (Zingiberaceae) from Thailand
}

\author{
Suppachai Tiyaworanant
}

Pharmaceutical Botany and Pharmacognosy Research Unit, Faculty of Pharmaceutical Sciences, Khon Kaen University, Khon Kaen 40002, Thailand

E-mail:suptiy@kku.ac.th; s.tiyaworanant@gmail.com

\begin{abstract}
A new species of Caulokaempferia (Zingiberaceae) from northern Thailand, C. chayaniana, is described and illustrated. The affinities of this new species with the morphologically similar taxon, C. larsenii Suksathan \& Triboun, are also discussed.
\end{abstract}

\section{Introduction}

The family Zingiberaceae may be considered the most important medicinal plant group of the Monocotyledonae in the Thai culture. Members of the family are widely used in food and medicine and some are also integral to the spiritual beliefs of Thai rural society. Our study of the genus Caulokaempferia in Thailand was inspired by an unknown taxon widely used by the "forest monks" in northeast Thailand as a major ingredient in the treatment of prostatic hyperplasia (enlarged prostate gland). As a result of intensive studies of the genus, this medicinal plant was recently recognised as C. phutokensis Picheans. (Picheansoonthon \& Koonterm 2008, Chaiyoot et al. 2008). Taxonomic study of the whole genus is ongoing with the aim of providing fundamental knowledge of this plant group for future drug research and development.

The genus Caulokaempferia K. Larsen comprises about 25 species, distributed from the Himalayas through south China, Indochina and Thailand, with its centre of diversity in Thailand (Chaiyoot 2007). At least 15 taxa have been reported recently from Thailand (Chaiyoot 2007) and the non-yellow flowered taxa transferred to a new genus, Jirawongsea Picheans. (Picheansoonthon et al. 2008).

An unknown population of this genus was first discovered during intensive fieldwork in October 2007 but the flowers were all past bloom. Follow-up excursions to the same location were carried out in May and July 2008, and June 2009 and further expanded to search for other populations. This unknown taxon is recognised as $C$. chayaniana in this paper. A full description, illustrations, and discussion of the morphological affinities of this species with C. larsenii Suksathan \& Triboun are included. 
Caulokaempferia chayaniana Tiyaw., sp. nov.

Diagnosis: Caulokaempferiae larsenii similis sed foliis amplexicaulibus, ligulis brevioribus (1.5-3 mm contra 6-9 mm longis), corollae lobo dorsali ovato, lobis lateralibus apicibus rotundatis, staminodiis apicibus emarginatis, filamentis longioribus (1-2 $\mathrm{mm}$ contra $0.5 \mathrm{~mm}$ longis) differt.

Holotype: Thailand: Mae Hong Son Province: Pai District: Doi Jik Jong, C. Picheansoonthon 1017, 10 July 2008 (BKF). Isotypes: BK, SING.

Perennial herb with short rhizome; roots fibrous, some forming a longish storage tuber. Pseudostem slender, erect, $12.5-37.4 \mathrm{~cm}$ long. Leaves 5-8, the lowermost 2-4 strongly reduced to bladeless leaf sheaths; lamina sessile, ovate to ovate-lanceolate, both sides glabrous, the largest ones $6.0-13.5 \times 1.7-5.7 \mathrm{~cm}$, with cordate, amplexicaul bases, apex acute to acuminate, margin slightly undulate; ligule membranous, 1.5-3.0 mm long, apex rounded. Inflorescence terminal, $3.5-8.5 \mathrm{~cm}$ long; peduncle glabrous, 2.2-5.5 cm long. Bracts 3-8, distichous, ovate to lanceolate, glabrous, 3.1$4.0 \times 0.5-1.7 \mathrm{~cm}$, acute, margin membranous, each enclosing a 1-3 flowered cincinnus; bracteoles elliptic, c. $1 \times 0.5 \mathrm{~cm}$, margin membranous. Flowers entirely yellow. Calyx tubular, glabrous, hidden in the bract, $1.2-1.5 \mathrm{~cm}$ long, split c. $2 \mathrm{~mm}$ down on one side, apex bi- or trilobed, or 3 or 4-dentate. Corolla tube $2.5-3.7 \mathrm{~cm}$ long, c. $2 \mathrm{~mm}$ wide, 3-lobed; dorsal lobe ovate, $1-1.3 \times 0.6-0.7 \mathrm{~cm}$, hooded with apex forming a c. $0.5 \mathrm{~mm}$ thorn-like point, lateral lobes ovate-oblong, $1.4-1.7 \times 0.5-0.6 \mathrm{~cm}$, apex rounded, hooded. Lateral staminodes obovate, $1.4-1.8 \times 1-1.3 \mathrm{~cm}$, apex emarginate. Labellum suborbicular, 2.4-3.2 × 1.2-2.2 cm, flat with saccate base, margin wavy. Functional stamen with very short filament, $1-2 \mathrm{~mm}$ long; anther oblong, c. $5 \times 3 \mathrm{~mm}$; anther crest broadly ovate, 3-4 × 5-6 mm, slightly reflex. Ovary oblong, 3-5 mm long, glabrous; stylodial glands 2, spherical c. $0.5 \mathrm{~mm}$ long; style linear (inserted between anther sacs); stigma cup-shape, 2-3 mm diam, margin ciliate. Fruit a unilocular fleshy capsule, ovoid-oblong, glabrous, $1.5-2 \times 0.5-0.6 \mathrm{~cm}$, greenish. Seed numerous, light brown, ellipsoid, c. $2 \mathrm{~mm}$ long. Flowering June-July; fruiting July-September. (Figs $1 \& 2$ )

Distribution: this species has so far been found only at the type location. It is distributed in a very limited area.

Ecology: this new species grows in moist granite clefts and in rock cleavages under evergreen lower montane scrub at an altitude of $900 \mathrm{~m}$.

Use: the whole plants, with other herbs, are used by the Shan ethnic group for gastric disorders.

Etymology: the specific epithet of this new taxon is named to honor Dr.Chayan Picheansoonthon, fellow of the Royal Institute of Thailand, in recognition of his contribution to our knowledge of the family Zingiberaceae in Thailand and Laos, in particular the genus Caulokaempferia. He has studied this genus and published several new species, the most recent of which include C. satunensis Picheans. (Picheansoonthon et al. 2007), C. phuwoaensis Picheans. \& Koonterm, C. phulangkaensis Picheans., C. phutokensis Picheans. (Picheansoonthon \& Koonterm 2008), and C. bolavenensis Picheans. \& Koonterm (Picheansoonthon et al. 2008).

Note: this new species is similar to C. larsenii Suksatan \& Triboun (Figs. 3a \& b) in several key characters, i.e. the open leaf sheaths, the presence of a ligule, the shape 
of the inflorescence, and the number of flower(s) per bract. However C. chayaniana differs from the latter taxon by its amplexicaul leaves; shorter ligules $(1.5-3 \mathrm{~mm}$ versus 6-9 $\mathrm{mm}$ ) with rounded apices; lanceolate to ovate bracts with pointed apices; calyx tubes with bi- or trilobed to 3 - or 4-dentate apices; ovate dorsal corolla lobes; and ovate to oblong lateral corolla lobes with emarginated apices.

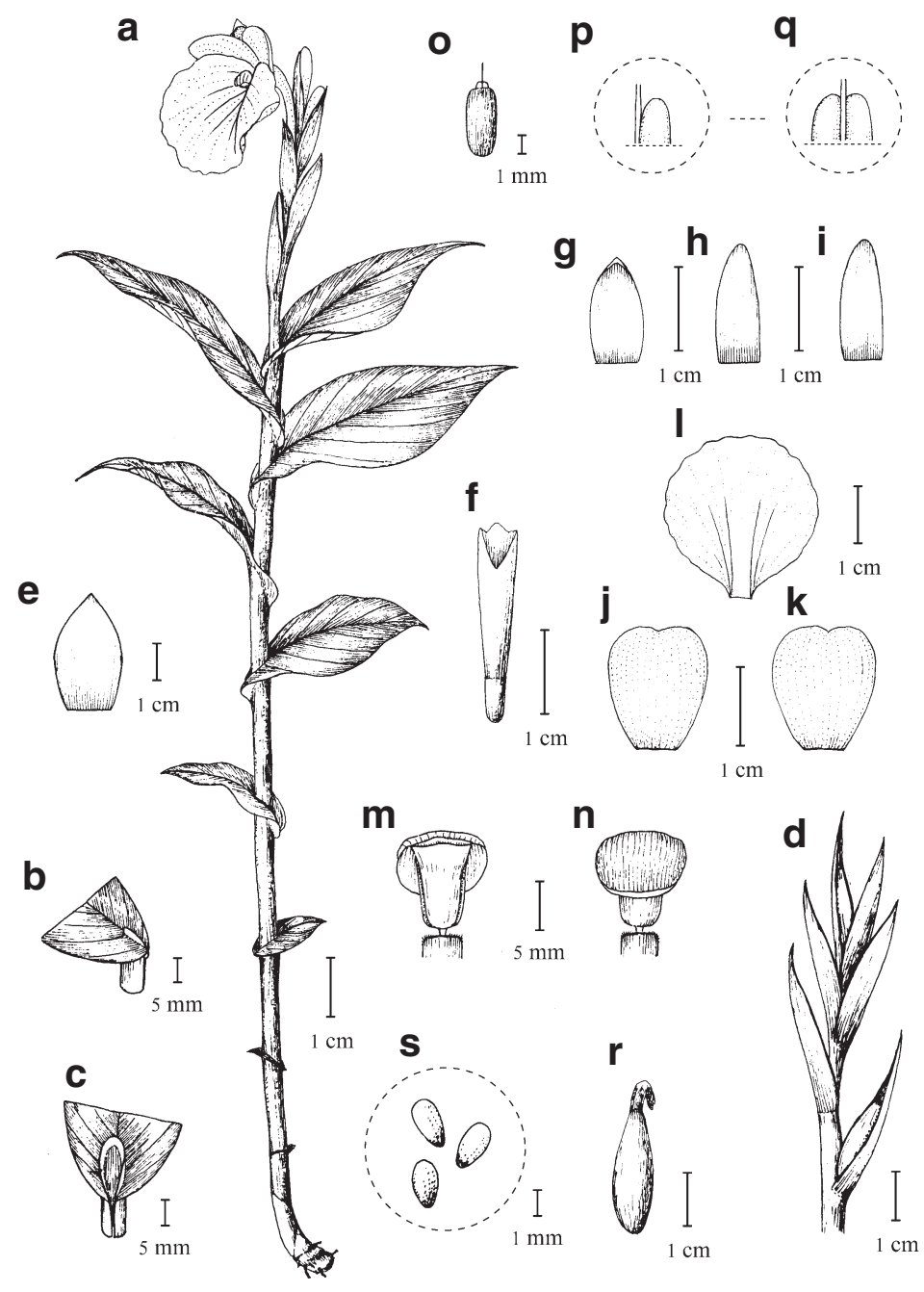

Fig. 1. Caulokaempferia chayaniana Tiyaw. a, habit; b \& c, leaf base, showing ligule (b, side view; c, front view); d, infructescence; e, bract; f, ovary and calyx tube; $\mathbf{g}$, dorsal corolla lobe; $\mathbf{h}$ \& i, lateral corolla lobes; $\mathbf{j}$ \& k, lateral staminodes; l, labellum; $\mathbf{m}$, stigma, anther and anther crest (ventral view); n, anther and anther crest (dorsal view); o, ovary, part of style and stylodial glands; p \& q, enlargement of stylodial glands (p, side view; q, front view); r, fruit; s, seeds (all from type locality, drawn by Chalermchoke Boonchit). 


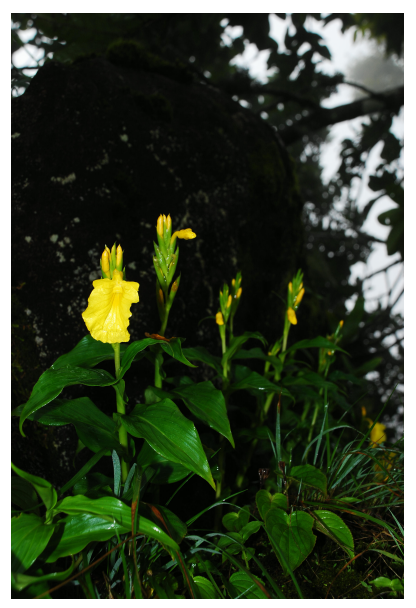

a
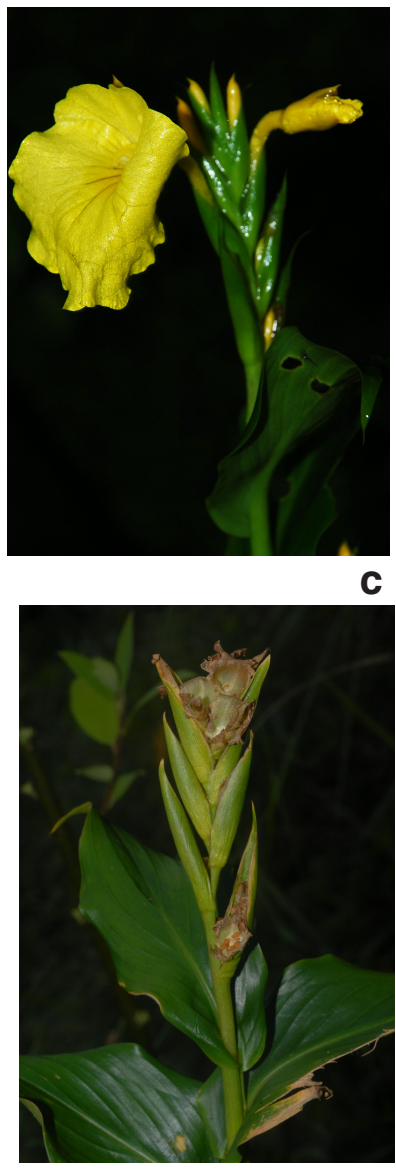

e

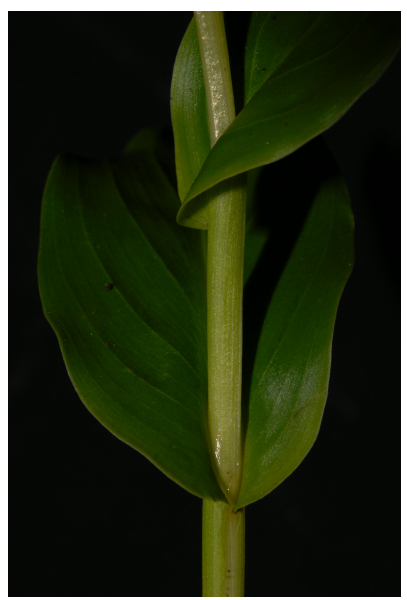

b
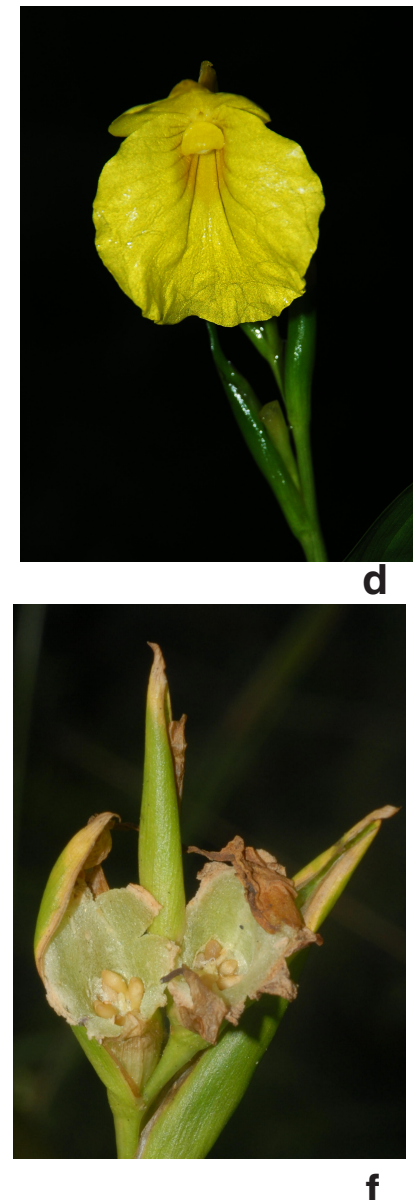

Fig. 2. Caulokaempferia chayaniana Tiyaw. a, habit; b, part of stem showing amplexicaul leaf bases; c, inflorescence showing distichous bracts and flowers; $\mathbf{d}$, flower (front view); e, infructescence; $\mathbf{f}$, infructescence with open capsules showing seeds inside (all from type locality; a, c \& d photographed by Pornpimon Wongsuwan; b, e \& f photographed by Chayan Picheansoonthon). 

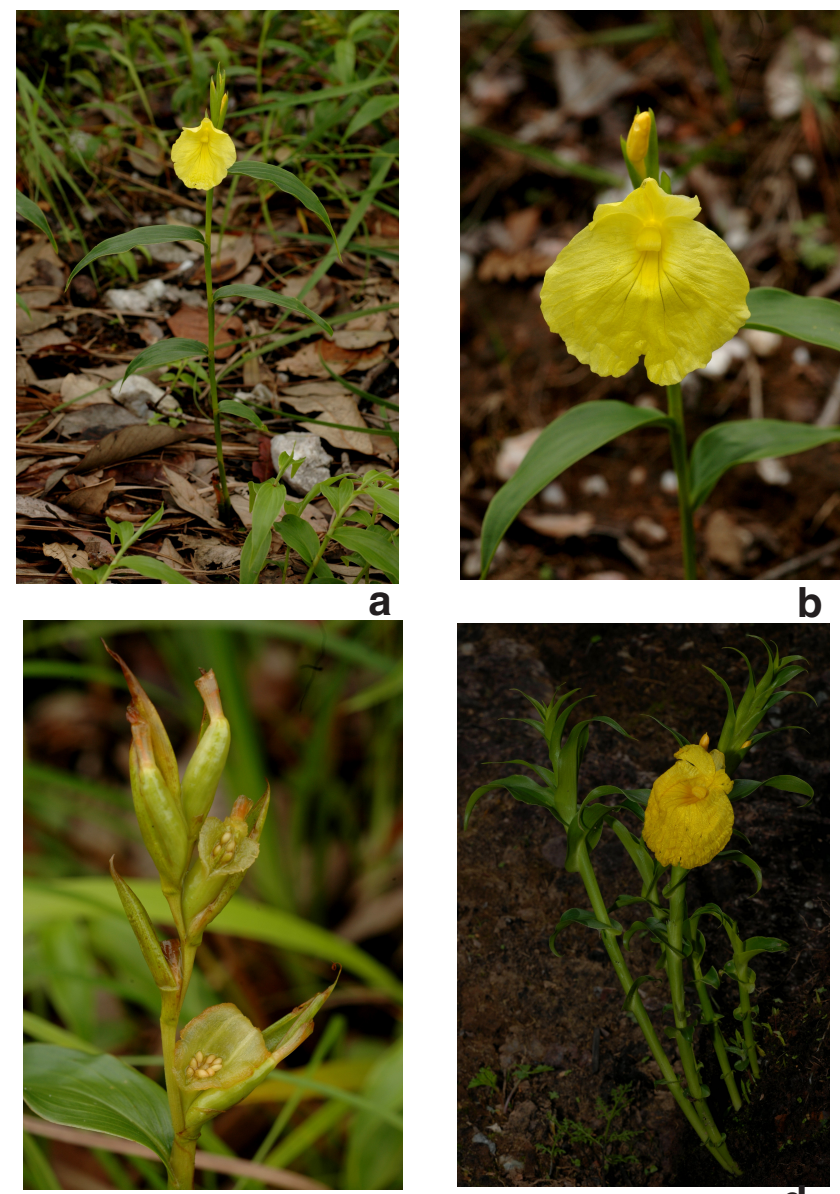

b
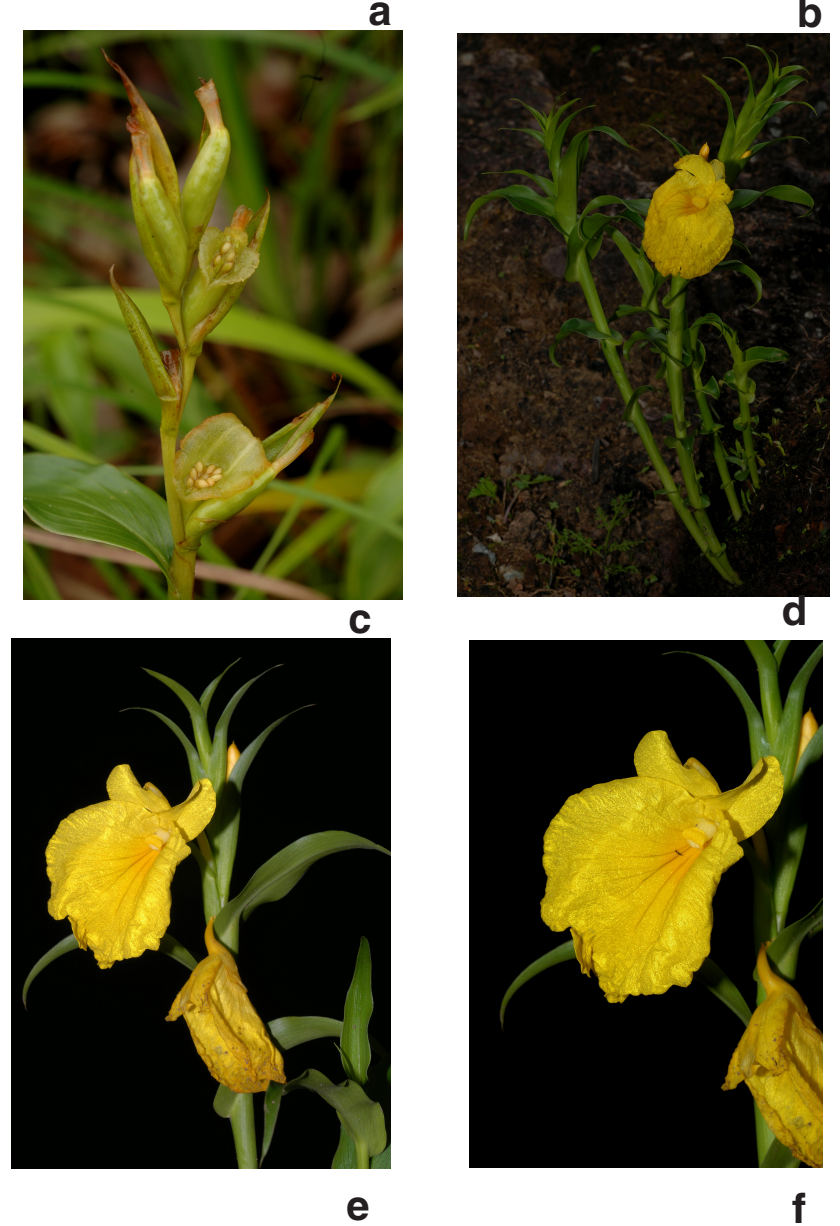

Fig. 3. a-c, Caulokaempferia larsenii Suksthan \& Triboun. $\mathbf{d}-\mathbf{f}$, Caulokaempferia amplexicalis Suksthan. a, habit; b, an inflorescence showing a flower; c, an infructescence; d, habit; e, an inflorescence showing the distichous bracts and a flower; $\mathbf{f}$, a flower (all plants from type localities, photographed by Chayan Picheansoonthon). 
This new taxon also resembles $C$. amplexicaulis Suksathan (Figs. 3e \& f) in its inflorescence structure and the amplexicaul leaves. The latter taxon is unique in its closed leaf-sheath without a ligule, Also, the inflorescence of C. amplexicaulis is characteristic in its leaf-like bracts with recurved apices subtending strictly one flower.

Biogeographically, it is worth noting that the type locations of C. chayaniana and C. amplexicaulis are on the clefts of the two high mountain peaks facing each other, approximately 100 kilometers apart, in the Pai Valley (Thailand, Mae Hong Son Province) adjacent to the border with Myanmar.

\section{Acknowledgments}

This research is a part of a five-year project ('Studies on fundamental botanical knowledge and DNA fingerprints of the Thai medicinal wan'), financially supported by the Thai Traditional Medical Knowledge Fund of the Ministry of Public Health. The author would like to thank Dr.Chayan Picheansoonthon (KKU) for his kind and generous advice; Dr. J. F. Veldkamp (L) for the Latin diagnosis; field assistance was provided by Chalermchoke Boonchit, Supachai Koonterm, Jeeradej Mayoe and Pornpimon Wongsuwan (all of KKU); and logistical support by Sarapee Fugprapai and Suriya Buabarn.

\section{References}

Chaiyoot A (2007) Molecular studies of the genus Caulokaempferia (Zingiberaceae) in Thailand and Laos. (Unpublished M.Sc. thesis: Khon Kaen University, Thailand)

Chaiyoot A, Sukrong S \& Picheansoonthon C (2008) Molecular studies of the genus Caulokaempferia (Zingiberaceae) distributed along the Mekhong River of northeastern Thailand and central Laos. Journal of Thai Traditional and Alternative Medicine 6(2): 203-211.

Larsen K, Suksatan P \& Triboun P (2005) Further studies in the genus Caulokaempferia (Zingiberaceae) in Thailand with description of two new species. Nordic Journal of Botany 23: 401-406.

Picheansoonthon P, Chaiyoot A \& Sukrong S (2008) Jirawongsea, a new genus of the family Zingiberaceae. Folia malaysiana 9(1): 1-16.

Picheansoonthon P \& Koonterm S (2008) Three new species of Caulokaempferia (Zingiberaceae) from southern Laos. Taiwania 53(3): 248-257.

Picheansoonthon P, Koonterm S, Chaiyoot A, Sukrong S \& Homchuen S (2008) A new species of Caulokaempferia (Zingiberaceae) from southern Thailand. Folia malaysiana 8(2): 53-61.

Picheansoonthon P, Lim CK, Sukrong S \& Chaiyoot A (2007) A new Caulokaempferia (Zingiberaceae) from Laos, with further information on other Caulokaempferia species from Laos. Natural History Bulletin of the Siam Society 56(1): 85-100.

Suksatan P \& Triboun P (2004) A new species of Caulokaempferia (Zingiberaceae) from Thailand. Edinburgh Journal of Botany 60(3): 513-516.

Manuscript received 23 July 2009, accepted 22 March 2010 